Research Article

\title{
New Cyclic Voltammetry of 3-(4-N-Pyridine-2-yl Benzene Sulfonamide Azo)-I-Nitroso Naphthol and the Use of it for Enhancement of Cobalt Oxide Nano Particles
}

\author{
Hussein Jasem Mohammed \\ Department of Chemistry, Faculty of Science, Kufa University, P.O. Box (21), Iraq. \\ Corresponding author. E-mail: Hussein.alshujairi@uokufa.edu.iq
}

Received: Apr. 24, 2017; Accepted: May 27, 2017; Published: Jun. 19, 2017.

Citation: Hussein Jasem Mohammed, New Cyclic Voltammetry of 3-(4-N-Pyridine-2-yl Benzene Sulfonamide Azo)-1-Nitroso Naphthol and the Use of it for Enhancement of Cobalt Oxide Nano Particles. Nano Biomed. Eng., 2017, 9(2): I35- 142.

DOI: 10.5101/nbe.v9i2.p135-142.

\begin{abstract}
The electrochemical behavior of the 3-(4-N-pyridine-2-yl benzene sulfonamide azo)-1-nitroso naphthol reagent and its complex with Co (II) has been studied at glassy carbon disk electrode in different supporting electrolyte at concentration $1 \mathrm{~mol}$ and scan rate $(100 \mathrm{mV} / \mathrm{s})$. 3-(4-N-pyridine-2yl benzene sulfonamide azo)-1-nitroso naphthol was used for enhance the properties of nano cobalt oxide by ligand exchange reaction on nanoparticles.
\end{abstract}

Keywords: Cyclic voltammetry; Cobalt oxide nano particles; 3-(4-N-pyridine-2-yl benzene sulfonamide azo)-1-nitroso naphthol

\section{Introduction}

Azo dyes belong to the one of the largest class of analytical reagents. Their important feature is electro activity which makes them an important reagent for the voltammetric determination of metal ions [1-3]. Recently, many researchers developed a sensitive method for the determination of metal ions with heterocyclic azo compounds as complexemetric agents by polarographic and voltammetric techniques. In addition, sulfa drugs alone have the ability to coordinate with different metal ions [4]. Heterocyclic azo compound reagents have received a great deal of attention as they are sensitive and selective chromogenic reagents. To continue improving the sensitivity, the selectivity and the metal complexes of this kind of regeants, the electrochemical characteristics of the reagents and their metal complexes have been studied [5-10]. 3-(4-N-pyridine2-yl benzene sulfonamide azo)-1-nitroso naphthol (PBSAN) is bidentate via azo group and hydroxyl group, which has the following structure:<smiles>O=[N+]([O-])c1c(O)c(N=Nc2ccc(S(=O)(=O)Nc3ccccc3)cc2)cc2ccccc12</smiles>

\section{Structure of reagent PBSAN}

Nano particles are microscopic particles with at least one dimension on the nanometer scale (1-100 nm). 
The transition from micro particles to nano particles can lead to a number of changes in physical properties. The two main factors in this area are the increase in the surface-to-volume-ratio and the size of the particles moving into the system, where quantum effects dominate [11]. The particle size gets smaller as the surface-area-to-volume ratio increases and, thus, leads to dominance of the actions of atoms on the surface than those in the bulk interior of the particles [12]. Ligand exchange reaction is a well-known method to exchange bound ligands on nano particles by simply mixing the free ligands with nano particles, which results in a replacement of the bound ligands by anew ligands (Scheme 1) [13].
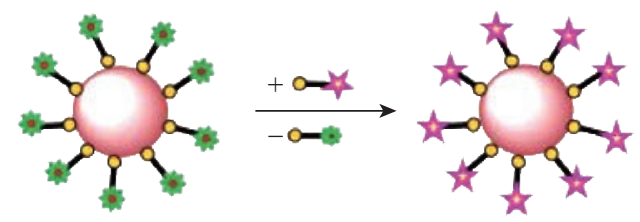

Scheme 1 Ligand exchange reaction on nano particles.

After the exchange of ligands, they may be used as biosensors, catalysts, or for optoelectronics applications. The particle size can also be adjusted by exchanging the ligands bound on particles [14].

\section{Experimental}

All chemicals used in this work were of analytical grade. Voltammetric experiments were carried out using a computer-controlled electro analysis system using an EZ-State by NuVant system. A three-electrode combination system was an $\mathrm{Ag} / \mathrm{AgCl}$ reference electrode, $\mathrm{Pt}$ wire auxiliary electrode and glassy carbon electrode as working electrode. The potential range selected was in the range of $1-1.25 \mathrm{mV}$. Atomic force microscopy (AFM) was carried out by AA2000 atomic force microscope of Angstrom Advanced Inc..

\section{Reagents}

\section{Cobalt stock solution ( $200 \mu \mathrm{g} / \mathrm{mL}$ )}

The solution was prepared by dissolving $(0.2018 \mathrm{~g})$ of cobalt chloride hexahydrate in $(250 \mathrm{~mL})$ of deionized water.

\section{3-(4-N-pyridine-2-yl benzene sulfonamide azo)- 1-nitroso naphthol $\left(1 * 10^{-3} \mathrm{~mol}\right)$}

This solution was prepared by using $0.0321 \mathrm{~g}$ reagent in $100 \mathrm{~mL}$ dimethyl sulfoxide.

\section{Results and Discussion \\ Electrochemical behavior of azo dye and redox mechanism in aqueous solution}

The cyclic voltammogrames of the investigated azo dyes showed 1-3 irreversible cathodic peaks [15, 16]. The number of peaks depends on the $\mathrm{pH}$ and the nature of the compounds. The peaks observed were due to the reduction of azo $-\mathrm{N}=\mathrm{N}-$ center. The reduction mechanism includes the formation of hydrazo derivatives followed by the cleavage of the $-\mathrm{N}==\mathrm{N}-$ bond and the final formation of amines [17, 18], according to the following formulas (Scheme 2).

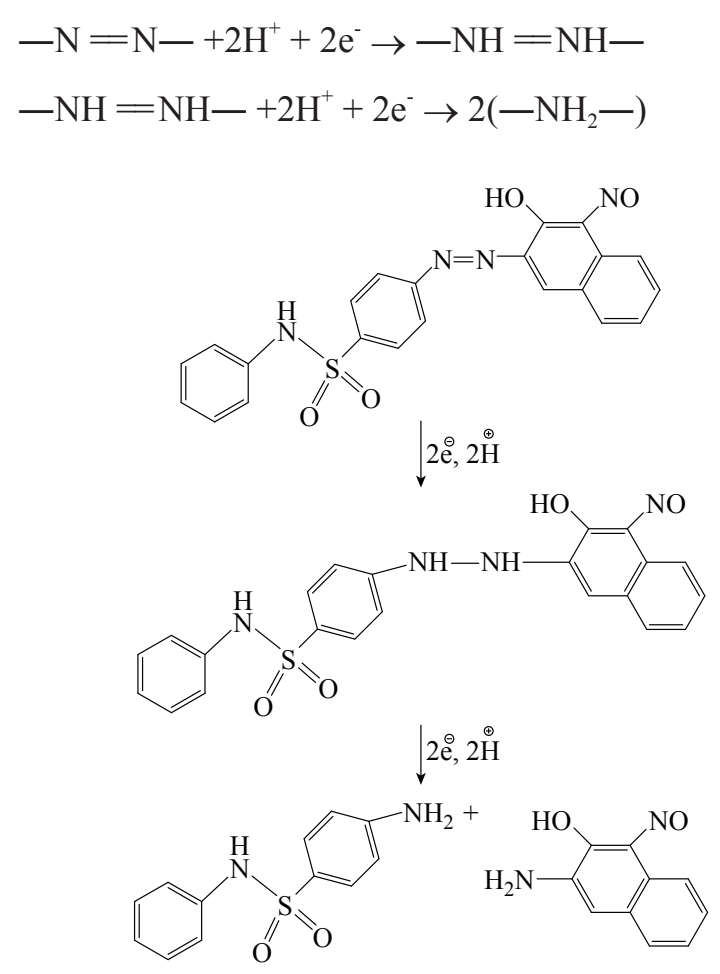

Scheme 2 Proposed mechanism of voltammetric reduction of reagent.

Different supporting electrolytes were used with the reagent at glassy carbon electrode (GCE) with the scan rate at $0.1 \mathrm{~V} / \mathrm{s}$ for all cyclic voltammogrames (Fig. 1-8). All voltammogrames presented a reduction peak of azo group $(-\mathrm{N}==\mathrm{N}-$ ) at the potential range of $-500-750 \mathrm{mV}$ ). The choice of the better supporting electrolyte depends on the higher current for the oxidation peak and the clarity of the peak (Table 1).

For the reagent PBSAN, it was proposed that the best supporting electrolyte was $\mathrm{Na}_{2} \mathrm{HPO}_{4}$ (Fig 6 ), and the current was the highest among the other electrolytes. Cyclic voltammogram revealed an irreversible electrochemical system in which the electron transfer rates were significantly lowere than 
that of mass transport and reduction in two steps. The first reduction attributed to the azo group giving a hydrazo derivative, and the second reduction peak broke the $\mathrm{N}-\mathrm{N}$ linkage to form two primary

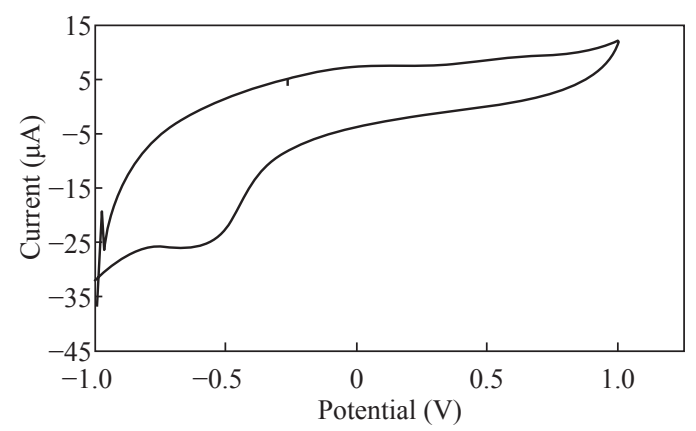

Fig. $1 \mathrm{CV}$ of PBSAN in the supporting electrolyte solution of $\mathrm{KCl}(1 \mathrm{~mol})$.

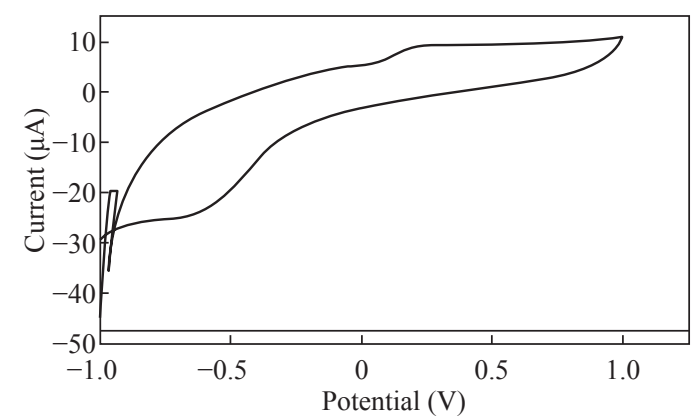

Fig. $3 \mathrm{CV}$ of PBSAN in the supporting electrolyte solution of $\mathrm{K}_{2} \mathrm{HPO}_{4}(1 \mathrm{~mol})$.

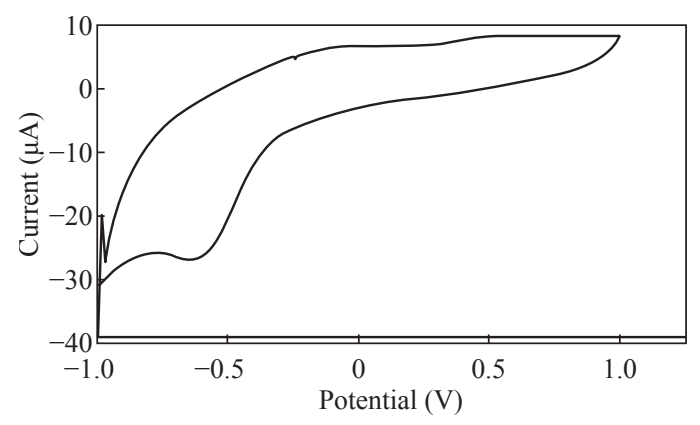

Fig. $5 \mathrm{CV}$ of PBSAN in the supporting electrolyte solution of $\mathrm{K}_{2} \mathrm{SO}_{4}(1 \mathrm{~mol})$.

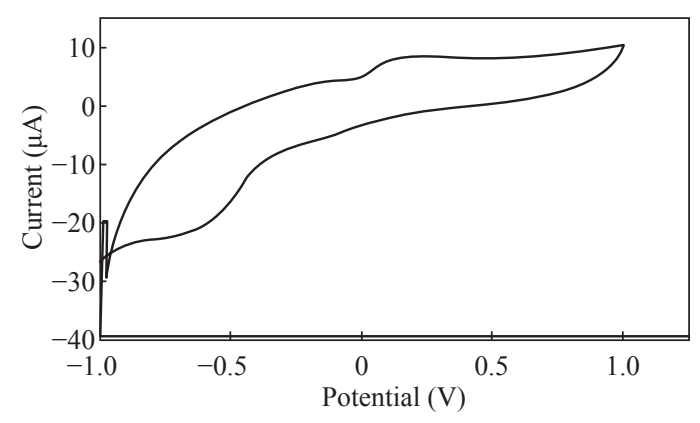

Fig. $7 \mathrm{CV}$ of PBSAN in the supporting electrolyte solution of $\mathrm{NaH}_{2} \mathrm{PO}_{4}(1 \mathrm{~mol})$. amine molecules. All current peak ratios showed an irreversibility of electrochemical system at different electrolytes, due to Ipc/Ipa $\neq 1$. The deviation from number one was due to the chemical reaction that

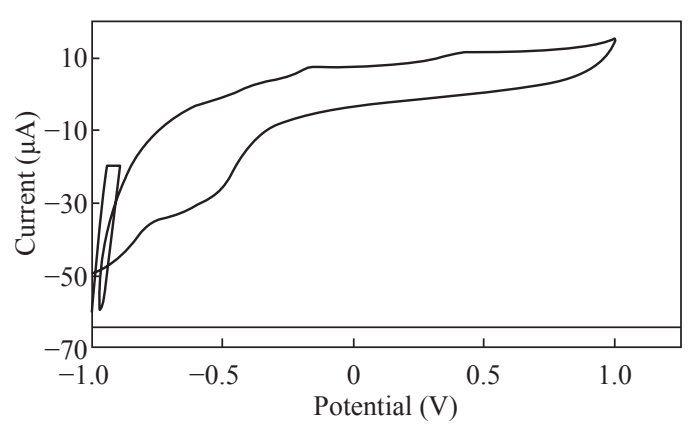

Fig. $2 \mathrm{CV}$ of PBSAN in the supporting electrolyte solution of $\mathrm{KClO}_{3}(1 \mathrm{~mol})$.

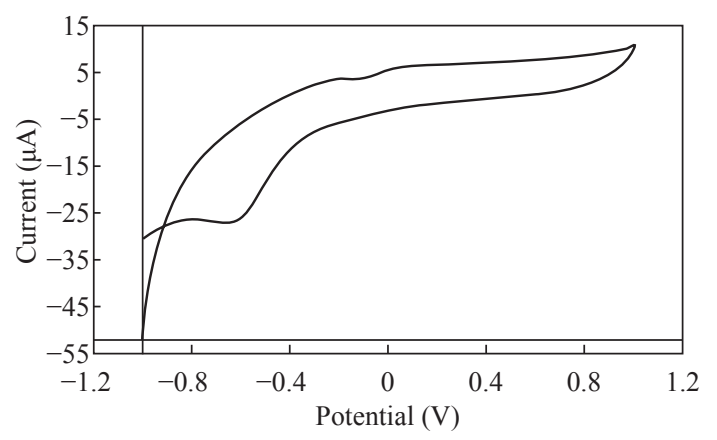

Fig. $4 \mathrm{CV}$ of PBSAN in the supporting electrolyte solution of $\mathrm{KNO}_{3}(1 \mathrm{~mol})$.

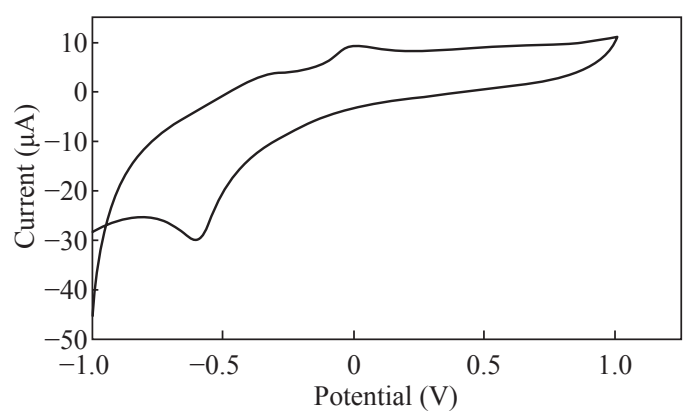

Fig. $6 \mathrm{CV}$ of PBSAN in the supporting electrolyte solution of $\mathrm{Na}_{2} \mathrm{HPO}_{4}(1 \mathrm{~mol})$.

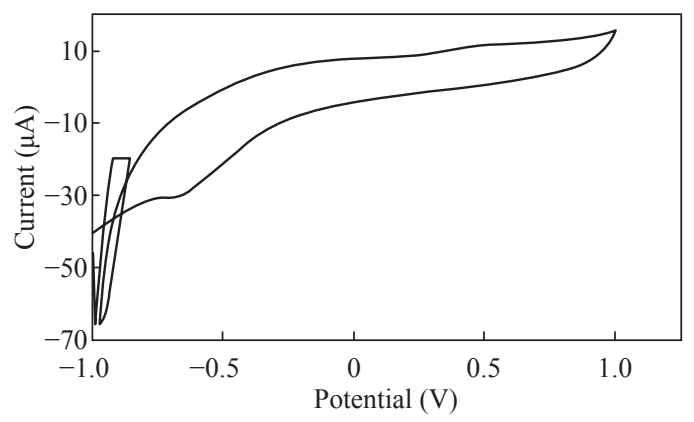

Fig. $8 \mathrm{CV}$ of PBSAN in supporting electrolyte solution of $\mathrm{NaCl}(1 \mathrm{~mol})$. 
Table 1 Current-Potential data of PBSAN in $1 \mathrm{~mol}$ of different supporting electrolyte solutions with the scan rate of $0.1 \mathrm{~V} / \mathrm{s}$

\begin{tabular}{|c|c|c|c|c|c|c|c|c|c|c|c|c|c|}
\hline No. & $\begin{array}{l}\text { Supporting } \\
\text { electrolyte }\end{array}$ & $\mathrm{Ia}_{1}(\mu \mathrm{A})$ & $\mathrm{Ea}_{1}(\mathrm{mV})$ & $\mathrm{Ia}_{2}(\mu \mathrm{A})$ & $\mathrm{Ea}_{2}(\mathrm{mV})$ & $\mathrm{Ia}_{3}(\mu \mathrm{A})$ & $\mathrm{Ea}_{3}(\mathrm{mV})$ & $\mathrm{Ic}_{1}(\mu \mathrm{A})$ & $\mathrm{Ec}_{1}(\mathrm{mV})$ & $\mathrm{Ic}_{2}(\mu \mathrm{A})$ & $\mathrm{Ec}_{2}(\mathrm{mV})$ & $\mathrm{Ic}_{3}(\mu \mathrm{A})$ & $\mathrm{Ec}_{3}(\mathrm{mV})$ \\
\hline 1 & $\mathrm{KCl}$ & 8.92 & 500 & 7.24 & 50.6 & 4.72 & 293 & 25.9 & 610 & - & - & - & - \\
\hline 2 & $\mathrm{KClO}_{3}$ & 11.5 & 409 & 7.41 & 142 & 2.06 & 406 & 27.5 & 519 & - & - & - & - \\
\hline 3 & $\mathrm{~K}_{2} \mathrm{HPO}_{4}$ & 9.09 & 205 & 3.86 & 185 & - & - & 23.4 & 601 & - & - & - & - \\
\hline 4 & $\mathrm{KNO}_{3}$ & 6.43 & 76.3 & 2.76 & 294 & - & - & 27.2 & 636 & - & - & - & - \\
\hline 5 & $\mathrm{~K}_{2} \mathrm{SO}_{4}$ & 8.43 & 587 & 6.85 & 76.6 & 3.88 & 341 & 26.7 & 623 & - & - & - & - \\
\hline 6 & $\mathrm{NaCl}$ & 11.5 & 474 & 7.41 & 116 & - & - & 30.3 & 649 & - & - & - & - \\
\hline 7 & $\mathrm{NaH}_{2} \mathrm{PO}_{4}$ & 8.46 & 171 & 3.46 & 202 & - & - & 21.7 & 645 & - & - & - & - \\
\hline 8 & $\mathrm{Na}_{2} \mathrm{HPO}_{4}$ & 11.6 & 470 & 7.41 & 137 & - & - & 29.8 & 645 & - & - & - & - \\
\hline 9 & TBABr & No res. & & & & & & & & & & & \\
\hline 10 & $\mathrm{BR}$ & No res. & & & & & & & & & & & \\
\hline
\end{tabular}

TBABr: Tetra-n-butylammonium bromide; BR: Britton-Robinson buffer

Table 2 Current-Potential data for PBSAN at $1 \mathrm{~mol}$ of different supporting electrolyte solutions with the scan rate of $0.1 \mathrm{~V} / \mathrm{s}$

\begin{tabular}{|c|c|c|c|c|c|c|c|c|}
\hline No & $\begin{array}{l}\text { Supporting } \\
\text { electrolyte }\end{array}$ & $\mathrm{Ea}_{1}(\mathrm{mV})$ & $\mathrm{Ec}_{1}(\mathrm{mV})$ & $\mathrm{Ia}_{1}(\mu \mathrm{A})$ & $\mathrm{Ic}_{1}(\mu \mathrm{A})$ & $\Delta \mathrm{E}_{1}(\mathrm{mV})$ & $\mathrm{E}_{1 / 2}(\mathrm{mV})$ & $\mathrm{Ia}_{1} / \mathrm{Ic}_{1}(\mu \mathrm{A})$ \\
\hline 1 & $\mathrm{Na}_{2} \mathrm{HPO}_{4}$ & 470 & 645 & 11.6 & 29.8 & 1115 & -87.5 & 0.3892 \\
\hline 2 & $\mathrm{NaH}_{2} \mathrm{PO}_{4}$ & 171 & 645 & 8.46 & 21.7 & 816 & -237 & 0.3890 \\
\hline 3 & $\mathrm{NaCl}$ & 474 & 649 & 11.5 & 30.3 & 1123 & -87.5 & 0.3795 \\
\hline 4 & $\mathrm{KCl}$ & 500 & 610 & 8.92 & 25.9 & 1110 & -55 & 0.3444 \\
\hline 5 & $\mathrm{KClO}_{3}$ & 409 & 519 & 11.5 & 27.5 & 928 & -55 & 0.4181 \\
\hline 6 & $\mathrm{KNO}_{3}$ & 76.3 & 636 & 6.43 & 27.1 & 712.3 & -279.85 & 0.2370 \\
\hline 7 & $\mathrm{~K}_{2} \mathrm{HPO}_{4}$ & 205 & 601 & 9.09 & 23.4 & 806 & -198 & 0.3880 \\
\hline
\end{tabular}

arised subsequent transmission electron. Such interactions can be complex, involving dissociation and isomerization [19] (Table 2).

The enhancement in the current of peak follows the following sequence: $\mathrm{Na}_{2} \mathrm{HPO}_{4}>\mathrm{NaCL}=\mathrm{KClO}_{3}>$ $\mathrm{K}_{2} \mathrm{HPO}_{4}>\mathrm{KCl}>\mathrm{NaH}_{2} \mathrm{PO}_{4}>\mathrm{K}_{2} \mathrm{SO}_{4}>\mathrm{KNO}_{3}$.

\section{Redox behavior of PBSAN-Co complex}

Different supporting electrolytes were used with the reagent PBSAN at GCE with the scan rate at $0.1 \mathrm{~V} / \mathrm{s}$ for all cyclic voltammogrames (Fig. 9-16) (Table 3).

The cyclic voltammogram of cobalt (II) complex showed two redox couple peaks in $1 \mathrm{~mol} \mathrm{Na}_{2} \mathrm{HPO}_{4}$ as revealed in Fig. 10. The first redox couple was at $\mathrm{Epc}_{1}$ $=-148 \mathrm{mV}$ vs. $\mathrm{Ag} / \mathrm{AgCl}\left(\mathrm{Ipc}_{1}=-2.73 \mu \mathrm{A}\right)$, and $\mathrm{Epa}_{1}$ $=-90.9 \mathrm{mV}$ vs. $\mathrm{Ag} / \mathrm{AgCl}\left(\mathrm{Ipa}_{1}=5.50 \mu \mathrm{A}\right)$. The second redox couple was at $\mathrm{Epc}_{2}=-531 \mathrm{mV}\left(\mathrm{Ipc}_{2}=9.36 \mu \mathrm{A}\right.$ ) and $\mathrm{Epa}_{2}=-398 \mathrm{mV}\left(\mathrm{Ipa}_{2}=1.64 \mu \mathrm{A}\right)($ Table 4). The first reduction peak was attributed to $\mathrm{Co}^{2+}+\mathrm{e}^{-}--$ $\mathrm{Co}^{1+}$, which was followed by the second reduction of cobalt (I) to cobalt (0) $\left(\mathrm{Co}^{+}+\mathrm{e}^{-}---\mathrm{Co}^{0}\right)$, when the scan was reversed. The first oxidation was attributed to the oxidation of $\mathrm{Co}^{0}$ to $\mathrm{Co}^{1+}$, while the second oxidation peak was attributed to the oxidation of cobalt (I) to cobalt (II) $\left(\mathrm{Co}^{1+}+\mathrm{e}^{-}---\mathrm{Co}^{2+}\right)$. We observed a difference between the redox couple of azo dye and it was complex with cobalt.

It was observed that $\Delta \mathrm{Ep}_{1}=57.1 \mathrm{mV}, \Delta \mathrm{Ep}_{2}=133$ $\mathrm{mV}$, and the ratio of the first anodic to cathodic peak currents $(\mathrm{Ipa} / \mathrm{Ipc} \neq 1)$ corresponded to more than one electron transfer process, which was also true with the second peak (Table 4). The difference in the value of Epc - Epa was $\Delta \mathrm{Ep}_{1}$, which was close to the value required for a reversible process, i.e. $59 \mathrm{mV}$, indicating that the reduction of cobalt (II) to cobalt (I) complex at silver electrode was reversible, while the reduction of cobalt (I) to cobalt ( 0 ) was an aquasi-reversible character [20-23].

The enhancement in the current of peak follows the following sequence: $\mathrm{K}_{2} \mathrm{HPO}_{4}>\mathrm{K}_{2} \mathrm{SO}_{4}>\mathrm{KNO}_{3}>$ $\mathrm{KClO}_{3}>\mathrm{Na}_{2} \mathrm{HPO}_{4}>\mathrm{NaH}_{2} \mathrm{PO}_{4}$.

\section{Enhancement of nano CoO particales Morphology and structure}

Nano particles are characterized by their small size, active function, large specific area, and strong 
interfacial interaction with the organic matrix of polymer [24]. Therefore, they can improve the physical and optical properties of the organic polymer, as well as provide impedance to environmental stress-caused cracking and aging [25].

AFM (atomic force microscopy) observations

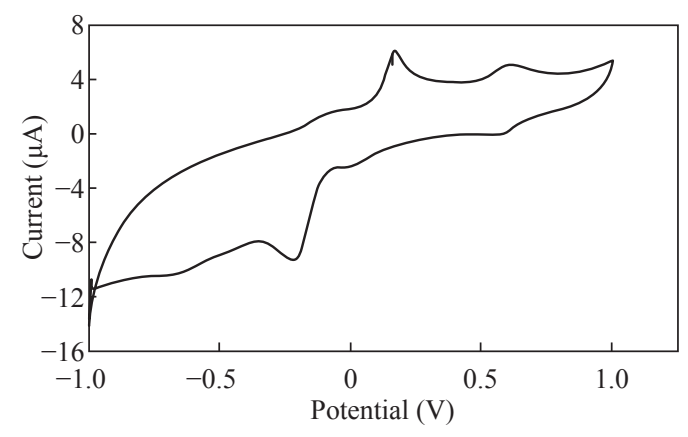

Fig. $9 \mathrm{CV}$ of PBSAN-Co in $\mathrm{NaH}_{2} \mathrm{PO}_{4}(1 \mathrm{~mol})$.

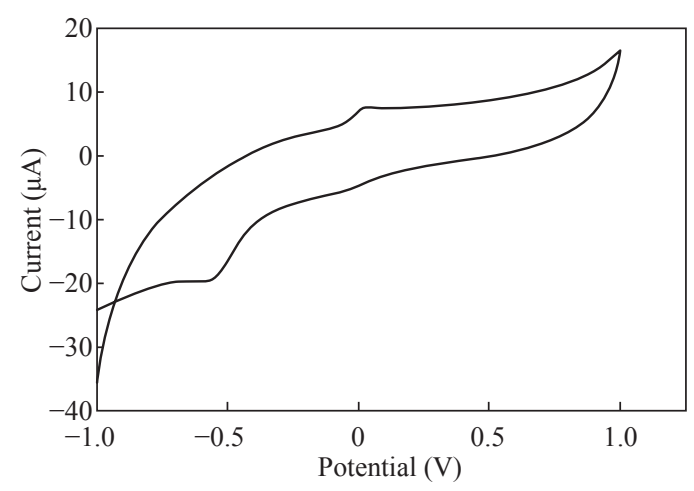

Fig. $11 \mathrm{CV}$ for PBSAN-Co in $\mathrm{KNO}_{3}(1 \mathrm{~mol})$.

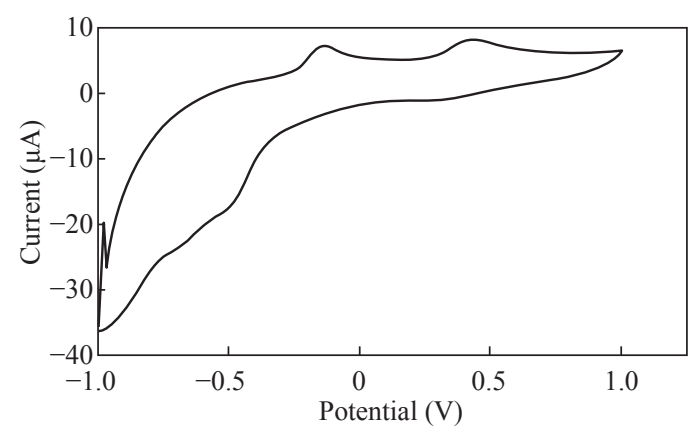

Fig. $13 \mathrm{CV}$ for PBSAN-Co in $\mathrm{K}_{2} \mathrm{SO}_{4}(1 \mathrm{~mol})$.

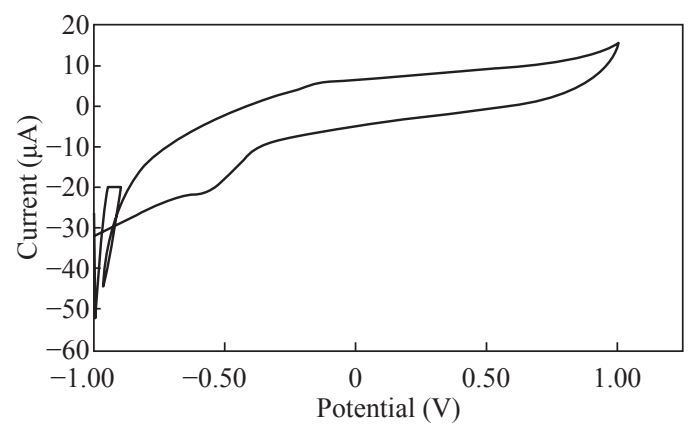

Fig. $15 \mathrm{CV}$ for PBSAN-Co in $\mathrm{KClO}_{3}(1 \mathrm{~mol})$. showed that the products were very aggregate and were converted to spherical particles (Fig. $17 \& 18$ ) after ligand exchange [26]. This morphological change might be partially due to the surface of Co ions which was bound to the original ligand at the highly reactive sites, such as tips or corners of the nano pyramids.

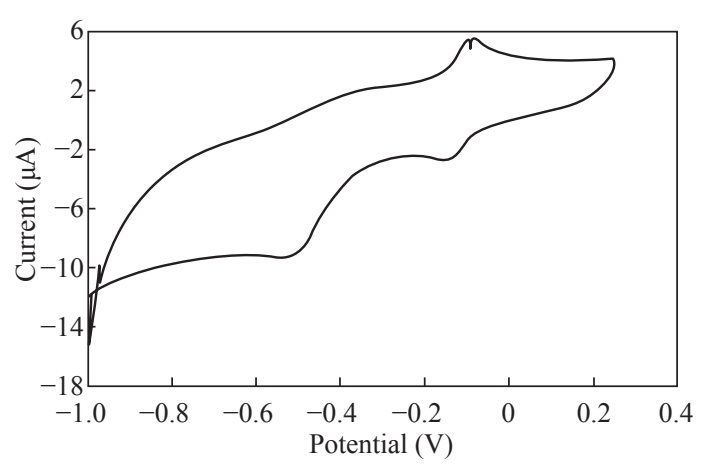

Fig. $10 \mathrm{CV}$ for PBSAN-Co in $\mathrm{Na}_{2} \mathrm{HPO}_{4}(1 \mathrm{~mol})$.

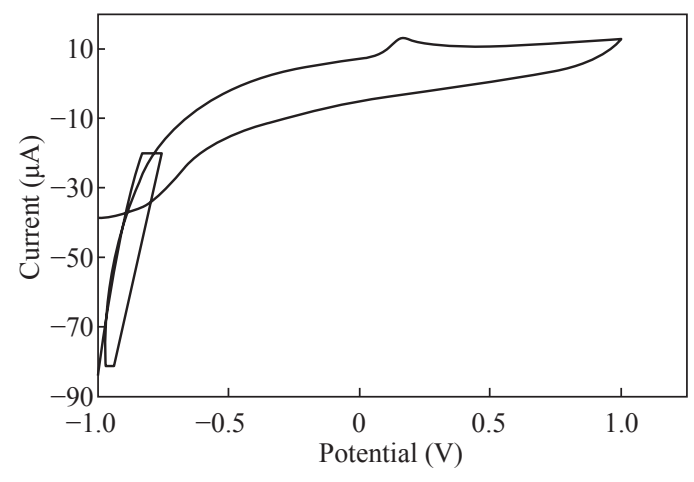

Fig. $12 \mathrm{CV}$ for PBSAN-Co in $\mathrm{K}_{2} \mathrm{HPO}_{4}(1 \mathrm{~mol})$.

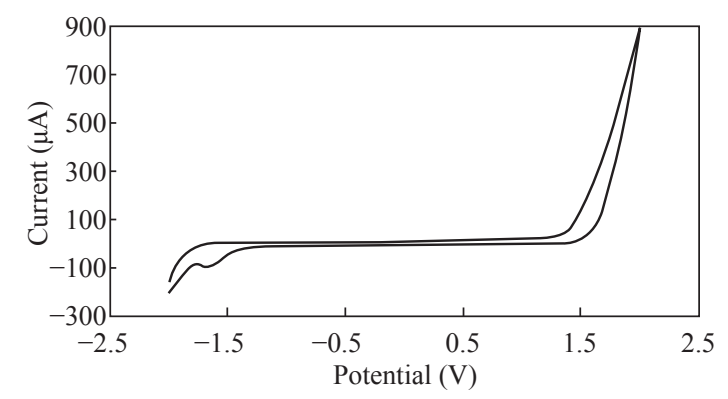

Fig. $14 \mathrm{CV}$ for PBSAN-Co in $\mathrm{KCl}(1 \mathrm{~mol})$.

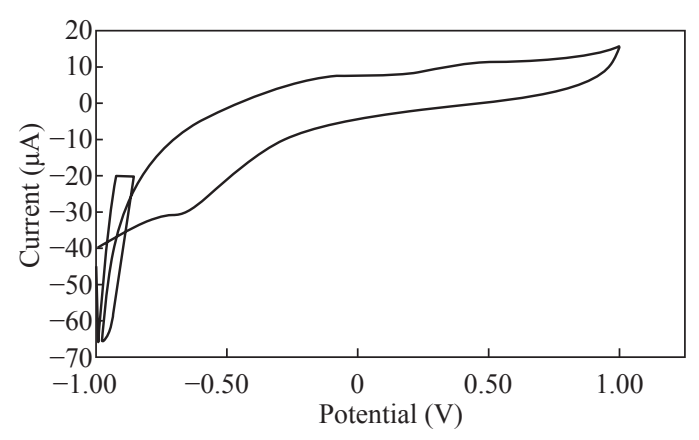

Fig. $16 \mathrm{CV}$ for PBSAN-Co in $\mathrm{NaCl}(1 \mathrm{~mol})$. 
Table 3 Current-Potential data for PBSAN-Co complex at $1 \mathrm{~mol}$ of different supporting electrolyte solutions at the scan rate of $0.1 \mathrm{~V} / \mathrm{s}$

\begin{tabular}{|c|c|c|c|c|c|c|c|c|c|c|c|c|c|}
\hline No. & $\begin{array}{l}\text { Supporting } \\
\text { electrolyte }\end{array}$ & $\mathrm{Ia}_{1}(\mu \mathrm{A})$ & $\mathrm{Ea}_{1}(\mathrm{mV})$ & $\mathrm{Ia}_{2}(\mu \mathrm{A})$ & $\mathrm{Ea}_{2}(\mathrm{mV})$ & $\mathrm{Ia}_{3}(\mu \mathrm{A})$ & $\mathrm{Ea}_{3}(\mathrm{mV})$ & $\mathrm{Ic}_{1}(\mu \mathrm{A})$ & $\mathrm{Ec}_{1}(\mathrm{mV})$ & $\mathrm{Ic}_{2}(\mu \mathrm{A})$ & $\mathrm{Ec}_{2}(\mathrm{mV})$ & $\mathrm{Ic}_{3}(\mu \mathrm{A})$ & $\mathrm{Ec}_{3}(\mathrm{mV})$ \\
\hline 1 & $\mathrm{Na}_{2} \mathrm{HPO}_{4}$ & 5.50 & -90.9 & 1.64 & -398 & - & - & 2.73 & 148 & 9.36 & 531 & - & - \\
\hline 2 & $\mathrm{KClO}_{3}$ & 6.01 & -111 & - & - & - & - & 21.1 & 584 & - & - & - & - \\
\hline 3 & $\mathrm{~K}_{2} \mathrm{HPO}_{4}$ & 13.1 & 166 & - & - & - & - & 7.31 & 146 & - & - & - & - \\
\hline 4 & $\mathrm{KNO}_{3}$ & 7.62 & 40.5 & 1.12 & -384 & - & - & 4.97 & 33.2 & 19.4 & 579 & - & - \\
\hline 5 & $\mathrm{~K}_{2} \mathrm{SO}_{4}$ & 8.25 & 452 & 7.20 & -137 & - & - & 1.36 & 305 & 16.9 & -488 & - & - \\
\hline 6 & $\mathrm{NaH}_{2} \mathrm{PO}_{4}$ & 4.98 & 621 & 5.09 & 171 & 1.37 & -93.9 & 55.9 & 574 & 2.41 & 10.1 & 9.45 & 224 \\
\hline 7 & $\mathrm{KCl}$ & - & - & - & - & - & - & 94.4 & 1.67 & - & - & - & - \\
\hline 8 & $\mathrm{NaCl}$ & No res. & & & & & & & & & & & \\
\hline
\end{tabular}

Table 4 Current - Potential data for PBSAN-Co in $1 \mathrm{~mol} \mathrm{Na}_{2} \mathrm{HPO}_{4}$ as the supporting electrolyte solution at the scan rate of $0.1 \mathrm{~V} / \mathrm{s}$

\begin{tabular}{|c|c|c|c|c|c|c|c|c|c|c|c|c|c|c|}
\hline Compound & $\begin{array}{c}\mathrm{Ea}_{1} \\
(\mathrm{mV})\end{array}$ & $\begin{array}{c}\mathrm{Ec}_{1} \\
(\mathrm{mV})\end{array}$ & $\begin{array}{c}\mathrm{Ia}_{1} \\
(\mu \mathrm{A})\end{array}$ & $\begin{array}{c}\mathrm{Ic}_{1} \\
(\mu \mathrm{A})\end{array}$ & $\begin{array}{l}\Delta \mathrm{Ep}_{1} \\
(\mathrm{mV})\end{array}$ & $\begin{array}{c}\left(\mathrm{Ipa}_{1} / \mathrm{Ipc}_{1}\right)_{1} \\
(\mu \mathrm{A})\end{array}$ & $\begin{array}{l}{\left[\mathrm{E}_{1 / 2}\right]_{1}} \\
(\mathrm{mV})\end{array}$ & $\begin{array}{c}\mathrm{Ea}_{2} \\
(\mathrm{mV})\end{array}$ & $\begin{array}{c}\mathrm{Ec}_{2} \\
(\mathrm{mV})\end{array}$ & $\begin{array}{c}\mathrm{Ia}_{2} \\
(\mu \mathrm{A})\end{array}$ & $\begin{array}{l}\mathrm{Ic}_{2} \\
(\mu \mathrm{A})\end{array}$ & $\begin{array}{l}\Delta \mathrm{Ep}_{2} \\
(\mathrm{mV})\end{array}$ & $\begin{array}{c}\left(\mathrm{Ipa}_{2} / \mathrm{Ipc}_{2}\right)_{2} \\
(\mu \mathrm{A})\end{array}$ & $\begin{array}{r}{ }_{2}\left[\mathrm{E}_{1 / 2}\right]_{2} \\
(\mathrm{mV})\end{array}$ \\
\hline PBSAN-Co & -90.9 & -148 & 5.50 & -2.73 & 57.1 & 2.01 & -119.4 & -398 & -531 & 1.64 & -9.36 & 133 & 0.175 & -464.5 \\
\hline
\end{tabular}
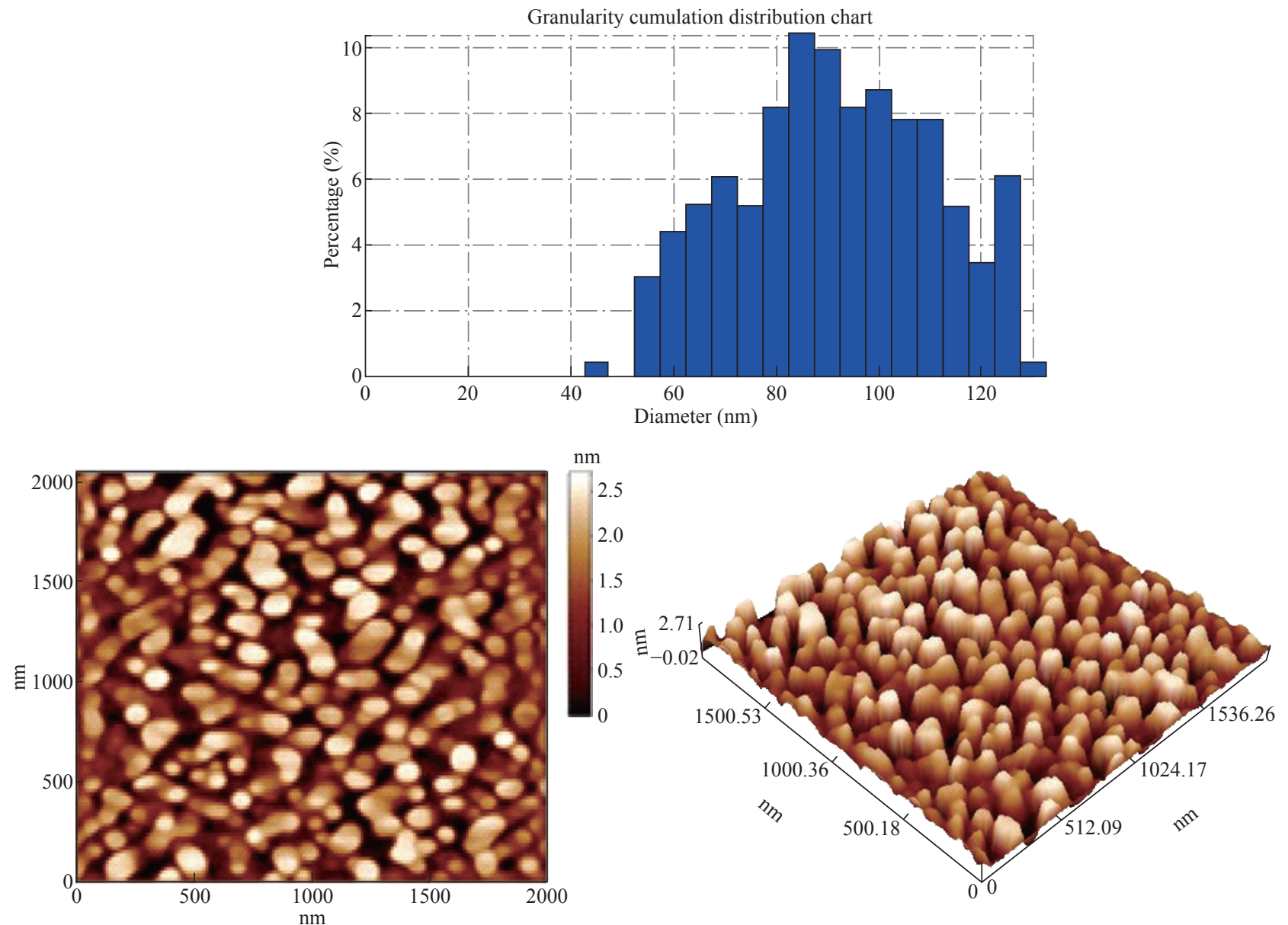

Fig. 17 The average diameter as determined by the AFM for $\mathrm{CoO}$ was $96.54 \mathrm{~nm}$ before ligand exchange.

They were stripped in the ligand exchange process. Etching of the surface of colloidal nano crystals capped by azo ligands or short chain alcohols has also been reported by other groups. On the other hand, the
AFM results of the $\mathrm{CoO}$ nano crystals showed that the average diameter as determined by the AFM was 96.54 $\mathrm{nm}$ for nano particles before ligands exchange and 89.03 for PBSAN after ligand exchange (Table $5 \& 6$ ). 

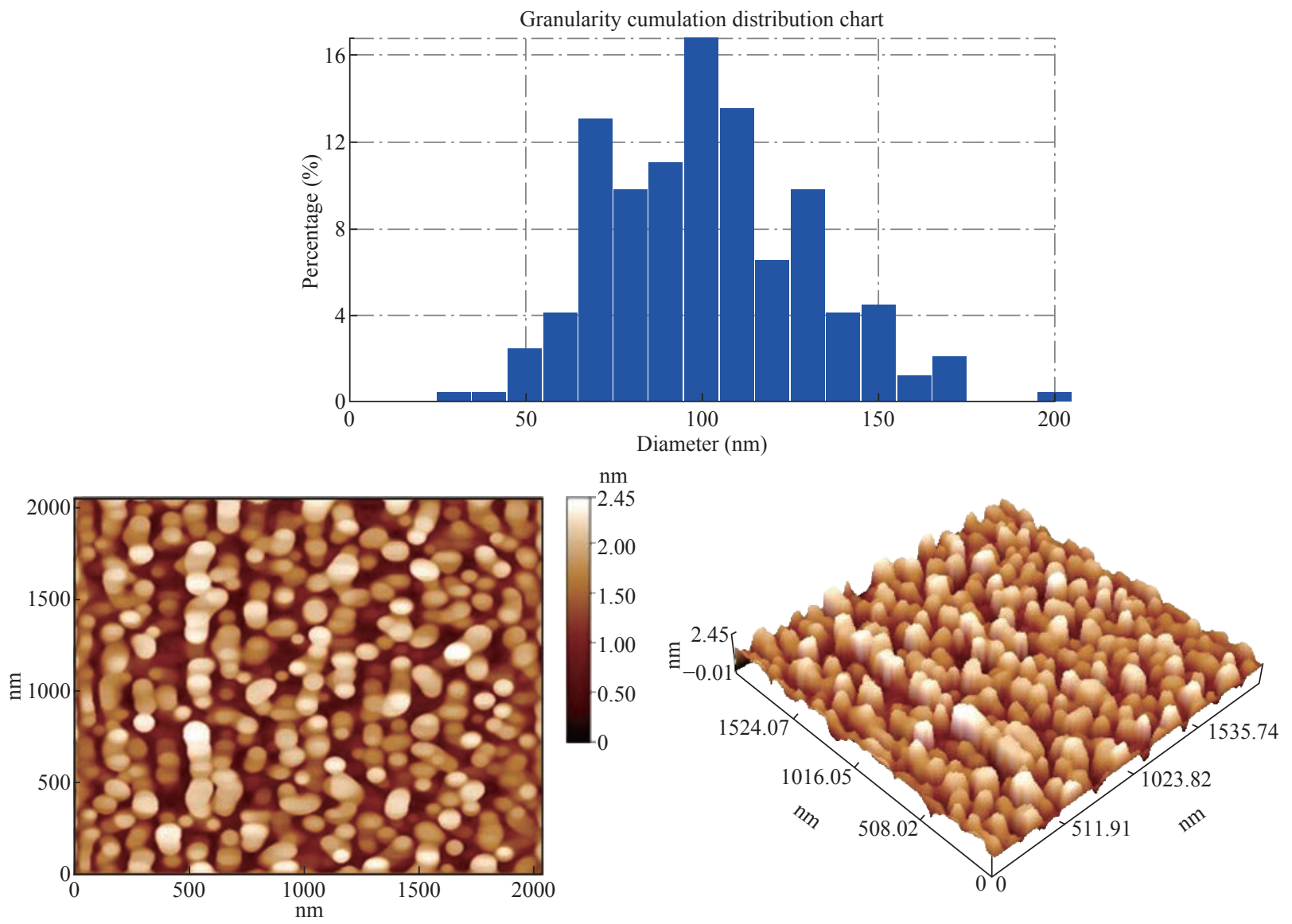

Fig. 18 The average diameter as determined by the AFM for Nano R1-CoO was $89.03 \mathrm{~nm}$ after ligand exchange.

Table 5 Diameters of Co before ligand exchange

\begin{tabular}{cccc}
\hline Status & $\begin{array}{c}\text { Grain size } \\
\text { (G.S.) }\end{array}$ & $\begin{array}{c}\text { Roughness } \\
\text { average (Ron.) }\end{array}$ & $\begin{array}{c}\text { Root mean } \\
\text { square (R.M.S) }\end{array}$ \\
\hline $\mathrm{CoO}$ & $96.54 \mathrm{~nm}$ & $0.621 \mathrm{~nm}$ & $0.730 \mathrm{~nm}$ \\
\hline
\end{tabular}

Table 6 Diameters of $\mathrm{CoO}$ after ligands exchange

\begin{tabular}{cccc}
\hline Status & $\begin{array}{c}\text { Grain size } \\
\text { (G.S.) }\end{array}$ & $\begin{array}{c}\text { Roughness } \\
\text { average (Ron.) }\end{array}$ & $\begin{array}{c}\text { Root mean } \\
\text { square (R.M.S) }\end{array}$ \\
\hline R1-CoO & $89.03 \mathrm{~nm}$ & $0.424 \mathrm{~nm}$ & $0.503 \mathrm{~nm}$ \\
\hline
\end{tabular}

Fig. 17 exhibits that the G.S. for $\mathrm{CoO}$ was $96.54 \mathrm{~nm}$, while Fig. 18 exhibits that the G.S. reduced to 89.03 $\mathrm{nm}$ for PBSAN after ligand exchange, which occurred due to the fact that R1 correlated with the metal oxide, so that the Ron. and R.M.S. in Table.6 decreased after the dye was added.

\section{Conclusions}

In this work, the cyclic voltammetric system of PBSAN led to the formation of the same hydrazine derivative which remained at the electrode surface<smiles>O=[N+]([O-])c1c(O)c(N=Nc2ccc(S(=O)(=O)Nc3ccccc3)cc2)cc2ccccc12</smiles>

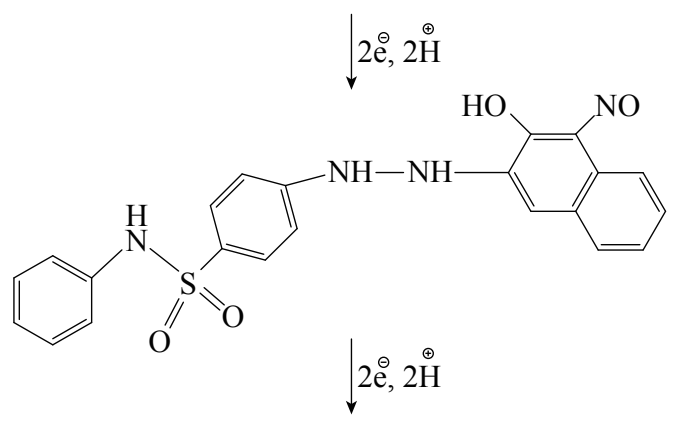<smiles>Nc1cc2ccccc2c(N=O)c1O</smiles>

according to the following equation:

The enhancement of nano particles of cobalt oxide 
was also investigated by ligand exchange mechanism with the azo dye of PBSAN.

\section{References}

[1] G.M.G. van den Berg, Potentials and potentialities of cathodic stripping voltammetry of trace elements in natural waters. Analytica Chimica Acta, 1991, 250: 265276.

[2] M.G. Paneli, A. Voulgaropoulos, Applications of adsorptive stripping voltammetry in the determination of trace and ultratrace metals. Electroanalysis, 1993, 5: 355373.

[3] J. Wang, J. Mahmoud, and J. Zadeii, Simultaneous measurements of trace metals by adsorptive stripping voltammetry. Electroanalysis, 1989, 1: 229-234.

[4] H.M. Jarallah, J.S. Hadi. Synthesis, characterization and thermal studies of 4-(2-hydroxy-3-methoxybenzylidene amino)-N-(pyridine-2-yl) Benzene Sulphonamide and their complexes. Journal of Basrah Researches, 2012, 38 : 1 .

[5] N. Menek, A polarographic and voltammetric behaviour of some azo dyes. PhD Thesis, Ondokuz Mayis University, Samsun, Turkey, 1994.

[6] Y. Karaman, N. Menek, F.A. Bicer, et al., Voltammetric investigations of 2, 2-azobispyridine zinc (II) and nickel (II) complexes. Int. J. Electrochem. Sci, 2015, 10: 31063116.

[7] M. Ucar, A.O. Solak, and N. Menek, Electrochemical behavior of 2-halogenated derivatives of N, N-dimethyl4-aminoazobenzene at mercury electrode. Analytical sciences, 2002, 18(9): 997-1002.

[8] S. Menati, A. Azadbakht, R. Azadbakht, et al., Synthesis, characterization, and electrochemical study of some novel, azo-containing Schiff bases and their Ni (II) complexes. Dyes and Pigments, 2013, 98(3): 499-506.

[9] S. Pysarevska, L. Dubenska, N. Shajnoga, et al., Polarographic investigation of reduction processes of gallium (III) complexes with some o, o-dihydroxysubstituted azo dyes. Chemistry of metals and alloys, 2009, 2(3-4): 194-201.

[10] A.G. Fogg, R. Ismail, R. Ahmad, et al, Discrete complexed ligand and catalytic nickel peaks in the differential pulse polarography and cathodic stripping voltammetry of Mordant Red 74. Microchemical Journal, 1997, 57(1): 110-114.

[11] M.M. Sinthiya, K. Ramamurthi, S. Mathuri1, et al., Synthesis of zinc ferrite $\left(\mathrm{ZnFe}_{2} \mathrm{O}_{4}\right)$ nanoparticles with different capping agents. Int. J. Chem Tech Res., 2015, 7: 2144-2149.

[12] V.J. Mohanraj, Y. Chen, Nanoparticles - a review. Trop J Pharm Res, 2006, 5(1): 561-573.

[13] S. Perumal, Mono-and multivalent interactions between thiol and amine ligands with noble metal nanoparticles. Ph.D Thesis, Freie Universität, Berlin, Germany, 2012.

[14] A.J. Canumalla, N. Al-Zamil, M. Phillips, et al., Redox and ligand exchange reactions of potential gold (I) and gold (III)-cyanide metabolites under biomimetic conditions. Journal of inorganic biochemistry, 2001, 85(1): 67-76.

[15] G.D. Levitskaya, N.P. Poperechnaya, and L.O. Dubenskaya, Polarographic behavior of eriochrome red $\mathrm{B}$ and its complexes with rare-earth ions. Journal of Analytical Chemistry, 2001, 56( 6): 552-556.

[16] L. Dubenska, H. Levytska, and N. Poperechna, Polarographic investigation of reduction process of some azo dyes and their complexes with rare-earths. Talanta, 2001, 54(2): 221-231.

[17] G.W. Latimer, Polargraphic behavior of metal chelates of o, ődihydroxyazo dyes. Talanta, 1968, 15(1): 1-14.

[18] D.K. Gosser, Cyclic voltammetry: Simulation and analysis of reaction mechanisms. VCH Publishers, 1993.

[19] C.H. Bamford, C.F.H. Tippert, R.G. Compton, Electrode kinetics: principles and methodology. Elsevier Science, 1986, 26: 17-21.

[20] A.J. Bard, L.R. Faulkner, Electrochemical methodes, fundamentals and application, 2nd Edition. Wiley, 2001.

[21] R.N. Patel, N. Singh, D.K. Patel, et al., Synthesis,characterization and superoxide dismutase studies of square pyramidal copper (II) complexes with bi and tri dentate polyamine ligands. Indian Journal of Chemistry A, 2007, 46(3): 422-427.

[22] P. Tharmaraj, D. Kodimunthiri, C.D. Sheela, et al., Synthesis, spectral studies and antibacterial activity of $\mathrm{Cu}$ (II), Co (II) and Ni (II) complexes of 1-(2-hydroxyphenyl)-3-phenyl--2-propen-1-one, N 2-[(3, 5-dimethyl-1H-pyrazol-1-yl) methyl] hydrazine. J Serb Chem Soc, 2009, 74(8-9): 927-938.

[23] P. Knopp, K. Wieghardt, B. Nuber, et al., Synthesis, electrochemistry, and spectroscopic and magnetic properties of new mononuclear and binuclear complexes of vanadium (III),-(IV, and-(V) containing the tridentate macrocycle 1,4,7-trimethyl-1,4,7-triazacyclononane (L). Crystal structures of $\left[\mathrm{L}_{2} \mathrm{~V}_{2}(\mathrm{acac})_{2}(\mu-\mathrm{O})\right] \mathrm{I} 2.2 \mathrm{H}_{2} \mathrm{O}$, $\left[\mathrm{L}_{2} \mathrm{~V}_{2} \mathrm{O}_{4}(\mu-\mathrm{O})\right] \cdot 14 \mathrm{H}_{2} \mathrm{O}$, and $\left[\mathrm{L}_{2} \mathrm{~V}_{2} \mathrm{O}_{2}(\mathrm{OH})_{2}(\mu-\mathrm{O})\right](\mathrm{ClO} 4)_{2}$. Inorganic Chemistry, 1990, 29(3): 363-371.

[24] A.R. Studart, E. Amstad, and L. Gauckler, Colloidal stabilization of nanoparticles in concentrated suspensions. Langmuir, 2007, 23(3): 1081-1090.

[25] G. Liu, Y.F. Li, F.Y. Yan, et al., Effect of nanoscale $\mathrm{SiO}_{2}$ and $\mathrm{TiO}_{2}$ as the fillers on the mechanical properties and aging behavior of linear low-density polyethylene lowdensity polyethylene blends. J . Polym Environ, 2005, 13: 339-348.

[26] A.A. Sayhood, M.J. Hussain, Synthesis of novel azo reagents derived from 4-aminoantipyrine and their applications of enhancement of silver nano particles. Der pharma chemica, 2015, 7(8): 50-58.

Copyright $\subset 2017$ Hussein Jasem Mohammed. This is an open-access article distributed under the terms of the Creative Commons Attribution License, which permits unrestricted use, distribution, and reproduction in any medium, provided the original author and source are credited. 